\title{
CAPITAL CONTROLS AND FOREIGN DIRECT INVESTMENT
}

\author{
Elizabeth Asiedu, asiedu@ku.edu \\ Department of Economics, University of Kansas \\ Donald Lien,dlien@utsa.edu \\ Department of Economics, University of Texas, San Antonio
}

\begin{abstract}
This paper examines the effects of three types of capital control policies: (i) the existence of multiple exchange rates (ii) controls on capital account and (iii) the stringency of requirements for the repatriation and/or surrender of export proceeds, on foreign direct investment flows. We examine how each capital control measure affects FDI across 75 developing countries over the period 1970-2000. Overall, we find that capital controls deter FDI. However the impact has changed over time. Specifically, prior to the 1990s, the only restriction that had a significant impact on FDI was the exchange rate structure. However, in the 1990s, all three measures of capital controls were influential, suggesting that investors have become discriminatory and punitive over time. In addition, the impact of liberalization on FDI varies by region. Capital account control is the only significant policy for East Asian and Pacific countries whereas exchange rate system and export restrictions are both important determinants of FDI in Latin America and Caribbean. None of the instruments has effects on FDI in Sub-Sahara Africa and Middle East \& North Africa.
\end{abstract}

Key words: Capital controls, capital flows, foreign direct investment, developing countries. 


\section{Capital Controls and Foreign Direct Investment Elizabeth Asiedu and Donald Lien}

\section{Introduction}

While economic miracles of some East Asian countries highlight the benefits of open markets, the 1997 Asian crisis rejuvenated the discussion on the merits of capital controls. Rodrik (1998) finds no relationship between capital account liberalization and growth. Krugman (1998) favors capital controls, at least temporarily. ${ }^{1}$ Indeed, the IMF almost reversed its longtime policy of pressuring countries to liberalize their investment framework. On the other hand, Eiche ngreen (2002) argues that imposing capital controls on developing countries amounts to a double standard. Quinn (1997) and Edwards (2001) both find a positive relationship between capital account liberalization and economic growth. An excellent review is provided in Eichengreen (2001).

Interestingly, most of the research on capital controls has focused on its impact on shortterm flows or the bad cholesterol. ${ }^{2}$ The argument is that, capital account liberalization increases short-term flows, which in turn makes the country vulnerable to a crisis. However, the impact of the crisis can be dilapidating and very costly in terms of growth, as was observed in some East Asian countries. As there is consensus that long- term flows, foreign direct investment (or the good cholesterol), promote growth, we need to examine the effects of capital controls on foreign direct investment (FDI). Conceivably, if capital controls have a negative impact on FDI, then the overall impact of imposing restrictions is unclear as it drives out both the bad and good

\footnotetext{
${ }^{1}$ During the 1997 Asian crisis, Krugman argued that Asian countries need at least a temporary period of capital controls

${ }^{2}$ Private foreign investment may be classified as short-term (mainly portfolio investment and bank loans) or longterm (mainly foreign direct investment).
} 
cholesterol. The question is which of the two forces dominates. Surprisingly, there is scant literature on this issue.

Furthermore, the negative effect of capital account liberalization on short-term flows is experienced mainly by countries that have access to international capital markets (i.e., industrialized and emerging-market countries). The reason is that most developing countries, in particular, the countries in dire need of foreign capital, receive very little if any portfolio investments. As a consequence, the impact of capital controls on private foreign investment is determined solely by how it affects FDI. Interestingly, the poor countries (mostly in SubSaharan Africa and South Asia) are also, by the IMF definition, on the average very restrictive on capital controls. An analysis on the effects of capital controls on FDI will provide useful policy guidelines for these countries.

This paper considers three types of capital controls: (i) the existence of multiple exchange rates for capital account transactions (ii) controls on capital account and (iii) the stringency of requirements for the repatriation and/or surrender of export proceeds. We examine how each control measure affects FDI across 75 developing countries over the period 1970-2000. It answers the following questions: (i) How has FDI responded to liberalization measures undertaken by countries? (ii) Has the impact of liberalization changed over time? (iii) Does the impact of liberalization vary by region? Has the experience of emerging markets with regards to FDI liberalization been different?

To the best of our knowledge, this is the first study that examines how various types of capital controls affect FDI flows. Most previous studies examine the impact of capital controls on growth and capital flows use only one of the indices, controls on capital account. Some studies, including Gastanaga et al (1998), Mody and Murshid (2000), and Hernandez et al 
(2001), construct an index summarizing the four measures. Both approaches are problematic. For our analysis, we introduce the measures as separate variables as countries typically use these instruments conjunctively. This paper is also the first study that systematically examines the impact of capital controls on FDI in a broad panel.

The remainder of the paper is organized as follows: Section 2 describes the two major types of capital controls and provides a brief literature review. Section 3 describes the data and the explanatory variables. Section 4 presents the empirical results followed by plausible explanations and policy implications in Section 5. Finally, Section 6 concludes.

\section{Capital Controls}

Capital controls can be broadly classified into two categories: (i) administrative or direct controls and (ii) market - based or indirect controls. Direct controls restrict capital transactions and the transfer of funds through outright prohibitions, including restrictions on capital account transactions, repatriation requirements, and restrictions on the use of funds. Market-based controls include multiple exchange rate systems, taxation of cross-border flows, and other indirect regulatory controls. These types of controls affect capital movements indirectly by increasing the costs associated with capital movements and associated transactions.

As pointed out in the previous section, only a few studies have examined the impact of capital controls on FDI. Furthermore, most of the analysis is based on a small number of countries. In addition, the studies often focus on emerging market (or middle income countries), and include very few low income countries - countries that need FDI the most, from their analysis. This is problematic since these poor countries, mainly in Sub-Saharan Africa and South Asia, are the worst culprits, when it comes to capital controls. For example, Desai et al (2002) 
analyze how restrictions on capital account transactions affect the investment decisions of U.S. firms abroad (such as asset allocation, transfer pricing, and dividend policies). Their analysis focuses on countries that have substantial U.S. multinational presence, thereby excluding most of the countries in SSA and South Asia. Hernandez and Carlson (2002) use data from 16 middle income countries to analyze the impact of restrictions on capital account and repatriation of export proceeds on the composition of capital flows. Montiel and Reinhart (1999) and Hernandez and Carlson (2002) examine how capital account restrictions affect the volume and composition of capital flows. The latter consider 15 emerging market countries and the former use data from 16 middle-income countries. Mody and Murshid (2002) is the sole exception. They consider 60 countries, 29 in SSA and 5 in South Asia.

In the literature the impact of capital controls on FDI is not unanimous. Gastanaga et al (1998), Desai et al (2002) and Mody and Murshid (2002) find evidence that capital controls deter FDI, while Montiel and Reinhart (1999) conclude that capital controls have a positive impact on FDI. Carlson and Hernandez (2002) and Hernandez et al (2001), on the other hand, find no significant relationship between capital flows and FDI. There are three plausible explanations for the inconsistent empirical results. First, as discussed earlier, the samples used vary across different studies. Second, the measures of capital controls vary across studies. Third, the studies cover different time periods. Indeed, the studies that cover a longer time period seem to find an inverse relationship between capital controls and FDI, suggesting that the impact of capital controls on FDI has changed over time. ${ }^{3}$

\footnotetext{
3 The analysis of Gastanaga et al (1998) cover 1970-1995, Desai et al (2002) focus on the period 1982-1994 and Mody and Murshid (2002) cover 1977-1998. Montiel and Reinhart (1999) focus on 1990-96 while Carlson and Hernandez (2002) and Hernandez et al (2001) analyze the impact of capital controls over the period 1987-97.
} 
With regards to measures of capital controls, Desai et al (2002) consider only one type of capital control, i.e., restrictions on capital account transactions. Carlson and Herna ndez (2002) consider two types of capital controls: restrictions on capital account transactions and restrictions on repatriation on export proceeds. Gastanaga et al (1998), Montiel and Reinhart (1999), Mody and Murshid (2002) and Hernandez et al (2001) construct an index that combines different types of capital controls. For example, Hernandez et al (2001) construct an index by adding two dummy variables, one indicating the presence of restrictions on payments for capital transactions, and the second the presence of surrender and/or repatriation requirements on export proceeds. One problem with using an index is that the impact of restrictions on FDI flows may vary by the type of restrictions. For example, some restrictions may be binding and others may not. It is therefore important to include each restriction separately. This type of analysis is particularly important for the formulation of policy.

This paper contributes to the literature in several ways. First, our analysis employs a more comprehensive dataset and spans a longer time period — the dataset covers 75 developing countries over the period 1970-99. ${ }^{4}$ An advantage of using a dataset that spans a large set of countries over a longer period is that it increases the degrees of freedom and therefore enhances the credibility of the results. It also allows us to examine whether the impact of capital controls on FDI has changed over time. Second, we consider three types of capital controls: the existence of multiple exchange rates (indirect capital control), restrictions on capital account transactions and restrictions on the repatriation of export proceeds (direct capital controls). Third, the paper examines the impact of capital controls on FDI after controlling for relevant country conditions that affect FDI flows. For example, a number of studies have shown that infrastructure availability, openness to trade and political instability affect FDI. However, only Gastanaga 
(1998) includes some of these variables in their studies. ${ }^{5}$ Indeed, the omission of important variables may explain the large estimates obtained by Montiel and Reinhart (1999). Fourth, this paper also examines whether the impact of capital controls on FDI varies by region. Specifically, policymakers in SSA have complained that FDI to their countries has not increased in spite of the fact that they have implemented reform policies. ${ }^{6}$ The paper examines whether the response of foreign direct investors to liberalization measures undertaken by various countries vary by country. Finally, we note that analyzing the impact of capital flows on FDI is particularly important for poor countries, especially countries in SSA and South Asia. The reason is that these countries do not have access to international capital markets. For such countries, the impact of capital controls on foreign investment is determined solely by how it affects FDI. About a third of the countries in our sample are located in SSA and South Asia (25 in SSA and 4 in South Asia). ${ }^{7}$ We next describe the variables included in the empirical analysis.

\section{Description of the Data and the Variables}

The analysis covers 75 developing countries over the period 1970-2000. As is standard in the literature, the dependent variable is the ratio of net FDI flows to GDP. The data on capital controls is from the International Monetary Fund (IMF) annual publication, Exchange Arrangements and Exchange Restrictions. ${ }^{8}$ The three measures of capital controls take on two values, one if there are no restrictions and zero otherwise. It is worth pointing out that the

\footnotetext{
4 See Table 6 for the list of countries.

5 A reason for the less rigorous analysis of the impact of FDI flows on capital flows is that the foci of the studies are little different. The papers cited in the text focus on how capital flows affect the composition of foreign investment and not FDI per say.

${ }^{6}$ See Asiedu (2002a) for a discussion of why FDI has not been responsive to policy changes in Africa.

${ }^{7}$ Note that this constitutes about $50 \%$ of the countries in Sub-Saharan Africa and South Asia.

${ }^{8}$ We thank Antu Murshid for making the data available to us.
} 
measures of capital controls used in most studies are based on the IMF data. ${ }^{9}$ Note that the focus of the paper is not to find the factors that affect FDI flows to developing countries. Our objective is to determine whether capital controls has a significant impact on FDI after controlling for other important factors that affect FDI. In choosing the control variables we draw from the FDI literature. Data on the independent variables, infrastructure, openness to trade, availability of natural resources, income per capita, growth rate of GDP, and financial depth is from the Word Bank's World Development Indicators (2002). Data on country risk is from Cross-National Time Series Data Archive and the data on the extent to which contracts are enforced in host countries is from the International Country Risk Guide (ICRG). Below we describe the variables that had a significant effect on FDI for our sample.

(i) Natural Resource Availability: In the literature, the relationship between natural resource intensity and FDI is far from unanimous. For example, Morisset (2000) and Asiedu (2002b) find a positive relationship between resource intensity and FDI. In contrast, Gastanaga et al (1998) find an inverse relationship while Noorbakhsh and Paloni (2002) find no significant relationship between the two variables. The conflicting results may be partly attributed to sample selection. The analysis of Gastanaga et al (1998) and Noorbakhsh and Paloni (2002) employ data for several developing countries while Morisset (2000) and Asiedu (2002b) focus exclusively on African countries. The inverse relationship between FDI and natural resources may also be explained by the fact that while natural resources exploration requires a large initial outlay, the continuing operations demand a small cash flow. Thus, after the initial phase, the FDI may be staggered. In fact, the bargaining power gained by the government may lead to a decrease in

\footnotetext{
${ }^{9}$ For a detailed discussion on the caveats of the IMF measure see Eichengreen (2001) and Quinn (1997). A few researchers have computed measures of capital controls based on data from other sources (Quinn, 1997, Shatz 2000). However, the data is available for only a few countries.
} 
FDI. For our analysis, we use the share of fuel and oil in total exports as a measure of natural resource availability. The coefficient of this variable is not determined a priori.

(ii) Openness of the Host Country: It is a standard hypothesis that openness promotes FDI [cf., Asiedu (2002b), Morisset (2000), Noorbakhsh and Paloni (2002)]. In the literature, the ratio of trade to GDP is often used as a measure of openness of a country. We therefore include trade/GDP in our regressions to examine the impact of openness on FDI.

(iii) Infrastructure Development: Good infrastructure increases the productivity of investment and therefore stimulates FDI flows [Wheeler \& Mody (1992), Loree \& Guisinger (1995), Morisset (2000) and Asiedu (2002a)]. As is standard in the literature, we use the number of telephones per 1000 population to measure infrastructure development.

(iv) Attractiveness of the Host Country Market: In the literature, the relationship between real GDP per capita and FDI is far from unanimous. Edwards (1990), Jaspersen et al (2000) and Asiedu (2002a) use the inverse of income per capita as a proxy for the return on capital and conclude that real GDP per capita is inversely related to FDI/GDP. In contrast, Schneider and Fry (1985), Tsai (1994), and Hausmann and Fernandez-Arias (2000) find a positive relationship between the two variables. The argument here is that higher domestic income and higher growth rates imply a greater demand for goods and services and therefore make the host country more attractive for FDI.

It is possible that the relationship between FDI and GDP per capita is U shaped. That is, the positive impact of income per capita on FDI flows "kicks in" only when income exceeds some threshold. We test this hypothesis by including GDP per capita and the square of GDP per capita in our regressions. ${ }^{10}$

\footnotetext{
${ }^{10}$ We thank Nicholas-Aris Charalambides for bringing this to our attention.
} 
(v) Financial Development: Foreign firms sometimes raise capital from host countries. Furthermore, there is less cost associated with capital transactions in countries with welldeveloped financial markets. As is standard in the literature, we include the ratio of liquid liabilities to GDP as a measure of financial depth. Our hypothesis is that financial development fosters FDI.

(vi) Quality of Institutions: Better institutional quality implies more FDI [Gastanaga et al (1998), Hausmann and Fernandez-Arias (2000)]. We use the degree to which contracts are enforceable in host countries to measure the reliability of institutions. We hypothesize that the coefficient of this variable is positive.

(vii) Country Risk: To measure country risk (or political instability), we use the number of strikes of a 1000 or more industrial workers that is aimed at national government policies. We argue that strikes can proxy for the stability of the government and therefore should have a negative impact on FDI flows. We tried other measures of political instability, such as number of assasinations, coups and civil wars, however, none of the various displayed a consistent relationship with FDI flows.

\section{Empirical Analysis}

As pointed out earlier, our objective is to examine how capital controls (or liberalization of capital controls) affects FDI flows. An appropriate framework for such an analysis is the fixed-effects panel estimation. ${ }^{11}$ This approach has two advantages. First, it allows the analyst to focus on changes within different units over time. Second, the estimates remain unbiased even

\footnotetext{
${ }^{11}$ An alternative to the fixed effects model is the random effects model. We rejected the random effects model based on the Hausman test.
} 
when data is missing for some time periods for some cross-sectional units. ${ }^{12}$ This advantage of fixed-effects estimation is particularly important for an analysis for SSA since data is not available for some years for several countries in the region. We first examine the effects of noncapital-control variables. These variables are chosen from existing literature. Estimation results are displayed in the first column of Table 2. They are consistent with theoretical predictions. The coefficients for openness, infrastructure, quality of institutions, and oil revenues are all statistically significant at $1 \%$ level. When the trade share increase by $1 \%$, the ratio of FDI to GDP will increase by $0.021 \%$. As the number of telephones per 1000 population increases by $1 \%$, the FDI ratio increases by $0.4 \%$. If contractual enforcement improves by one level, the FDI ratio will increase by $0.218 \%$. As conjectured, oil revenue has a negative impact on FDI: a $1 \%$ increase in the oil revenue share leads to $0.022 \%$ decrease in the FDI ratio.

Both GDP and the square GDP have significant impacts on FDI (at the 1\% level). A country with a larger GDP finds a larger increase in the FDI ratio as GPD increases. It displays a nonlinear threshold effect. The coefficient for GDP growth rate is marginally significant at the $1 \%$ level: when GDP grows $1 \%$ more, the FDI ratio increases by $0.025 \%$.

The coefficients for financial development and political instability are both statistically significant at the $10 \%$ level. When the money supply ratio increases by $1 \%$, the FDI ratio increases by $0.01 \%$ accordingly. As the number of strikes against the national government increases by one, the FDI ratio decreases by $0.131 \%$.

Column 2 of Table 2 displays estimation results when capital control variables are incorporated into the equation. There are minor changes in the coefficients of non-capital control variables. The coefficient for each capital control variable is statistically significant at the $1 \%$ level. An open capital account increases the FDI ratio by $0.543 \%$. Unitary exchange rate

\footnotetext{
${ }^{12}$ The unbalanced panel causes no problem if the missing data is not correlated with the idiosyncratic errors.
} 
improves the ratio by $0.537 \%$ whereas removal of export restrictions promotes the ratio by 0.619\%. Thus, over the whole sample period (1970 - 1999), capital account control policy and multiple exchange rate system have equal adverse effects on FDI. Export restrictions, however, are the most damaging policies.

We next examine how the effects may vary over time. Specifically we allow each capital control variable to have different effects over the periods of 1970s, 1980s and 1990s. Column 3 presents the estimation results. Although the changes in the coefficients for non-capital-control variables are more visible, the new estimates remain qualitatively similar to the original ones. Table 3 summaries the temporal pattern of the effects of each capital control variable. Before 1990, multiple exchange rate system is the only control variable that produces negative effects on FDI. During the 1990s, each capital control policy adversely affects FDI. Capital account control is the most influential policy (an open capital account improves FDI by $0.921 \%$ ), followed by export restrictions $(0.816 \%)$ and multiple exchange rate system $(0.667 \%)$. While during 1970s and 1980s some capital control policies may not affect FDI, in 1990s any of these policies will be costly. Thus, as far as recent years are concerned, the positive effects of capital control liberalization on long-term capital flow are significant enough to tradeoff the possible negative effects on short-term capital flows.

To examine the regional effects, we introduce regional dummy variable one by one into the equation. The results are presented in Table 4. In each equation, the new estimates for the coefficients for non-capital-control variables are somewhat different from the original ones but remain qualitatively similar in terms of signs and p values. Table 5 summaries the regional pattern of the effects of each capital control policy. None of these policies has any impact in 
Sub-Saharan Africa or Middle East \& North Africa. ${ }^{13}$ Note that these countries are endowed with small FDI. ${ }^{14}$ The above results therefore provide a pessimistic perspective indicating that trade liberalization will not help promote FDI. For East Asia and Pacific, capital account control is the only policy that deters FDI and its impact is highly significant. The open capital account policy will increase FDI by $3.764 \%$. In Latin America and Caribbean, export restrictions and multiple exchange rate system are responsible for low FDI flows. Elimination of export restrictions improves FDI by $1.623 \%$ whereas unitary exchange rate increases FDI by $0.362 \%$. For emerging market as a group, ${ }^{15}$ both capital account control and exchange rate system have significant adverse effects on FDI. Overall the effects of each capital control policy vary substantially from region to region.

\section{Plausible Explanations and Policy Implications}

Investors have become more discriminatory and punitive over time. In the 1970s and 1980s, countries were not rewarded (punished) for removing (imposing) capital controls. The situation changed in the 1990s. Thus, it is more rewarding (costly) to liberalize (to impose restrictions) in the 1990s than in the previous decades. The ineffectiveness of liberalization in SSA and Middle East may be explained by the fact that FDI in those regions are resourceseeking, mainly in fuel, oil and mineral resources. Such investments are less sensitive to policy environment or country conditions. For example, among African countries, Angola, an oil rich

\footnotetext{
13 The insignificance of capital controls for Sub-Saharan Africa is consistent with the empirical results of Asiedu (2002b).

${ }^{14}$ For example over the period 1990-99, the average FDI/GDP was 2.4\% for Sub-Saharan Africa and $1.3 \%$ for Middle East \& North Africa. This compares with an average of $4.1 \%$ for East Asia, $4.5 \%$ for Latin America and $2.8 \%$ for all developing countries.

${ }^{15}$ Emerging market countries are Argentina, Brazil, Chile, Colombia, Ecuador, Indonesia, Korea Rep, Malaysia, Mexico, Peru, Philippines, Singapore, Thailand and Venezuela.
} 
country ranked one in terms of FDI receipts in $1998 .{ }^{16}$ That same year, the country was classified as the most unstable country in the region (UNTCAD, 1998). Another plausible explanation is that foreign investors do not consider liberalization moves by countries in the region as credible. According to a World Bank survey, the single main deterrent to investment in Africa is the fear of policy reversal (World Bank, 1994). Thus the risk of policy reversal makes FDI less responsive to policy changes. Indeed, this lends credence to the arguments made by some African leaders that they are "discriminated" against by foreign investors and that foreign investors have refused to reach out to countries in the region, despite reform efforts and even sometimes providing incentives, such as tax breaks to investors. Does this imply that countries in the region should not liberalize? Probably not! There are other benefits from liberalization such as removing distortion.

Emerging markets benefit more from liberalization than other countries. However, as pointed out earlier, capital account liberalization also implies increased short-term capital flows, which might be destabilizing to the economy. Thus emerging market countries need to balance the trade-off from the benefits that accrue from FDI, such as technology transfer and employment with the cost associated with increased short-term flows. One plausible solution is to implement policies that will affect only hort-term flows. However, that is a tricky and difficult venture. The reason is that imposing controls on short-term capital sends a bad signal to all foreign investors. Furthermore, it creates uncertainty—which is a deterrent for all types of investments. Another important implication of the results is that policies should be country specific, since the effect of liberalization varies by country and region.

\footnotetext{
${ }^{16}$ Oil accounts for about $45 \%$ of GDP and $95 \%$ percent of total exports for Angola.
} 


\section{Conclusion}

In this paper we examine the effects of three types of capital control policies on foreign direct investment flows: (i) the existence of multiple exchange rates for capital account transactions, (ii) controls on capital account, and (iii) the stringency of requirements for the repatriation and surrender of export proceeds. The approach is important because countries typically use these instruments conjunctively. To the best of our knowledge, this is the first study that examines the impact of various types of capital controls on FDI flows. In addition, our analysis covers a wide range of countries, 75 developing countries.

Overall, we find that capital controls deter FDI. However, the impact has changed over time. Specifically, prior to the 1990s, the only restriction that had a significant impact on FDI was the exchange rate structure. However, in the 1990s, all three measures of capital controls

were influential. In addition, the impact of liberalization on FDI varies by region. Capital account control is the only significant policy for East Asian and Pacific countries whereas exchange rate system and export restrictions are both important determinants of FDI in Latin America and Caribbean. None of the instruments has effects on FDI in Sub-Sahara Africa and Middle East \& North Africa. 


\section{References}

Asiedu, Elizabeth (2002a). "On the Determinants of Foreign Direct Investment to Developing Countries: Is Africa Different?"World Development, 30 (1), 107-19.

Asiedu, Elizabeth (2002b). "Aggressive Trade Reform and Infrastructure Development: A Solution to Africa's Foreign Direct Investment Woes?" mimeo.

Carlson, Mark and Leonardo Hernandez (2002). "Determinants and Repercussions of the Composition of Capital Inflows," Board of Governors of the Federal Reserve System International Finance Discussion Paper Number 717.

Desai, Mihir, C. Fritz Foley and James Hines (2002). "Capital Controls, Liberalizations, and Foreign Direct Investment," Mimeo.

Edwards, S. (1990). “Capital Flows, Foreign Direct Investment, and Debt — Equity Swaps in Developing Countries,” NBER Working Paper no. 3497.

Eichengreen, Barry (2002). "Capital Account Liberalization: What do the Cross-Country Studies Tell Us? World Bank Economic Review, 15 (3), 341-365.

Gastanaga, Victor, Jeffrey B. Nugent and Bistra Pashamova (1998). "Host Country Reforms and FDI Inflows: How Much Difference Do They Make?" World Development, 26 (7), 12991314.

Hausmann, Ricardo and Eduardo Fernandez-Arias (2000). “The New Wave of Capital Inflows: Sea Change or Just Another Title?" Inter-American Development Bank Working Paper \# 417.

Hernandez, Leonardo, Pamela Mellado and Rodrigo Valdes (2001) “Determinants of Private 
Capital Flows in the 1970s and 1990s: Is there Evidence of Contagion?" IMF Working Paper WP/01/64.

Jaspersen, Frederick Z., Anthony H. Aylward and A.D. Knox (2000). "The Effects of Risk on Private Investment: Africa Compared with Other Developing Areas," in Paul Collier and Catherine Pattillo (eds), Investment and Risk in Africa, pp. 71-95. New York: St Martin's Press.

Krugman, Paul (1998). “Malaysia’s Opportunity” Mimeo available at http://www.pkarchive.org/crises/MalayasiaOpporunity.html

Loree, David W., and Stephen Guisinger (1995). "Policy and Non-Policy Determinants of U.S. Equity Foreign Direct Investment,” Journal of Business Studies, 26, (2) 281-299.

Mody, Ashoka and Antu P. Murshid (2002). "Growing Up with Capital Flows," IMF Working Paper WP/02/75.

Montiel, Peter and Carmen M. Reinhart (1999). "Do Capital Controls and Macroeconomic Policies Influence the Volume and Composition of Capital Flows? Evidence from the 1990s," Journal of International Money and Finance, 18, 619-635.

Morrisset, Piere (2000). "Foreign Direct Investment to Africa: Policies also Matter," Transnational Corporation, 9 (2), 107-125.

Noorbakhsh and Paloni (2001). "Human Capital and FDI Inflows to Developing Countries: New Empirical Evidence," World Development, 26 (7), 1593-1610.

Quinn Dennis (1997). "The Correlates of Change in International Financial Regulation," American Political Science Review, 91 (3), 531-551

Schneider, Friedrich and Bruno S. Frey (1985). "Economic and Political Determinants of Foreign Direct Investment," World Development, 13 (2), 161-175. 
Tsai, Pan-Long (1994). "Determinants of Foreign Direct Investment and its Impact on Economic Growth," Journal of Economic Development, 19, 137-163.

Wheeler, D. and Ashoka Mody (1992). "International Investment Location Decisions: The Case of US Firms," Journal of International Economics, 33, 57-76.

World Bank (1994). "East Africa Sur vey of Foreign Investors” Mimeo.

World Bank (2002). World Development Indicators on CD-Rom. 
Table 1: Summary Statistics, 1970-2000

\begin{tabular}{|l|cccc|}
\hline Variables & Mean & Std Dev & Min & Max \\
\hline $100^{*}$ (FDI/GDP) & 1.435 & 2.343 & -16.6 & 17.17 \\
$100^{*}$ (Imports+Exports)/GDP & 65.211 & 49.202 & 6.32 & 439.03 \\
Log (Phones per 1000 population) & 2.999 & 1.551 & -1.609 & 6.155 \\
GDP per Capita & 2,698 & 3,776 & 98.78 & 25,684 \\
GDP Growth & 3.651 & 5.243 & -26.28 & 33.99 \\
$100 *(\mathrm{M} 2 / \mathrm{GDP})$ & 33.474 & 19.913 & 5.24 & 132.48 \\
Share of fuel and minerals in Total Exports (Percent) & 15.554 & 26.032 & 0 & 99.78 \\
Enforcement of Contracts & 5.868 & 1.797 & 1 & 10 \\
Number of Strikes & 0.269 & 0.740 & 0 & 7 \\
\hline
\end{tabular}


Table 2. Fixed Effects Estimation

\begin{tabular}{|c|c|c|c|}
\hline Variable & (1) & $(2)$ & (3) \\
\hline \multirow[t]{2}{*}{ Intercept } & $22.401^{*+3 * 4}$ & $22.474^{* 2 * x+4}$ & $16.382^{* * 4}$ \\
\hline & $(.000)$ & $(.000)$ & $(.009)$ \\
\hline \multirow[t]{2}{*}{$100 *$ (Imports+Exports)/GDP } & $0.021^{* * *}$ & $0.019^{* * * *}$ & $0.020^{* * *}$ \\
\hline & $(.000)$ & $(.000)$ & $(.000)$ \\
\hline \multirow[t]{2}{*}{ Log (Phones per 1000 population) } & $0.400^{* * *}$ & $0.313^{* *}$ & 0.159 \\
\hline & $(.002)$ & $(.015)$ & $(.338)$ \\
\hline \multirow[t]{2}{*}{$100 * \mathrm{M} 2 / \mathrm{GDP}$} & $0.010^{*}$ & $0.013^{* *}$ & $0.012^{* *}$ \\
\hline & $(.083)$ & $(.027)$ & $(.040)$ \\
\hline \multirow[t]{2}{*}{ LGDPC $=$ Log $($ GDP per Capita $)$} & $-6.474^{* * *}$ & $-6.414^{* * *}$ & $-4.665^{* * *}$ \\
\hline & $(.000)$ & $(.000)$ & $(.005)$ \\
\hline \multirow[t]{2}{*}{ LGDPC *LGDPC } & $0.409^{* * *}$ & $0.401^{* * *}$ & $0.295^{* * *}$ \\
\hline & $(.000)$ & $(.000)$ & $(.006)$ \\
\hline \multirow[t]{2}{*}{ GDP Growth } & $0.025^{* *}$ & $0.024^{* *}$ & $0.019^{*}$ \\
\hline & $(.013)$ & $(.016)$ & $(.059)$ \\
\hline \multirow[t]{2}{*}{ Number of Strikes } & $-0.131^{*}$ & $-0.142^{* *}$ & $-0.148^{* *}$ \\
\hline & $(.072)$ & $(.048)$ & $(.038)$ \\
\hline \multirow[t]{2}{*}{ Enforcement of Contracts } & $0.218^{* * *}$ & $0.148^{* * *}$ & 0.070 \\
\hline & $(.000)$ & $(.001)$ & $(.143)$ \\
\hline \multirow[t]{2}{*}{ Share of oil in Total Exports (Percent) } & $-0.022^{* * *}$ & $-0.023^{* * *}$ & $-0.021^{* * *}$ \\
\hline & $(.000)$ & $(.000)$ & $(.000)$ \\
\hline \multirow[t]{2}{*}{$\mathrm{KA}=\operatorname{lag}$ (Dummy equals 1 if capital accounts is open). } & & $0.543^{* * *}$ & 0.516 \\
\hline & & $(.006)$ & $(.160)$ \\
\hline \multirow[t]{2}{*}{$\mathrm{ER}=$ lag (Equals 1 if Exchange rate structure is unitary) } & & $0.537^{* * * *}$ & $0.594^{* * *}$ \\
\hline & & $(.000)$ & $(.004)$ \\
\hline \multirow[t]{2}{*}{$E X=\operatorname{lag}$ (Equals 1 if there are no restrictions on export proceeds) } & & $0.619^{* * * *}$ & -0.026 \\
\hline & & $(.001)$ & $(.952)$ \\
\hline \multirow[t]{2}{*}{ KA* Dummy for 1980 s } & & & -0.325 \\
\hline & & & $(.462)$ \\
\hline \multirow[t]{2}{*}{ ER* Dummy for 1980 s } & & & -0.168 \\
\hline & & & $(.347)$ \\
\hline
\end{tabular}


KA*Dummy for 1990 s

0.404

ER*Dummy for 1990 s

(.310)

EX*Dummy for 1990

0.074

EX*Dummy for 1990 s

(.751)

$0.842^{*}$

(.084)

Number of Countries

75

75

75

Number of Observations

1398

1398

1398

Notes: P-values are in parenthesis and $* * *, * *$, and $*$ denote significance at $0.01,0.05$, and 0.10 levels respectively. 
Table 3. FDI Gains from Liberalization for Total Sample, 1970-1999.

\begin{tabular}{lcccc}
\hline Variable & $1970-79$ & $1980-89$ & $1990-99$ & $1970-99$ \\
\hline Capital Account & 0.516 & 0.191 & $.921^{* * * *}$ & $0.543^{* * * *}$ \\
(KA) & $(.160)$ & $(.572)$ & $(.000)$ & $(.006)$ \\
& $0.594^{* * *}$ & $0.426^{* *}$ & $0.667^{* * *}$ & $0.537^{* * *}$ \\
Structure of & $(.004)$ & $(.014)$ & $(.000)$ & $(.000)$ \\
Exchange Rate (ER) & -0.026 & 0.329 & $0.816^{* * *}$ & $0.619^{* * *}$ \\
Repatriation of & $(.952)$ & $(.429)$ & $(.000)$ & $(.001)$ \\
Export Proceeds & & & & \\
(EX) & & & & \\
\hline
\end{tabular}

Notes: $\mathrm{P}$-values are in parenthesis and $* * *, * *$, and $*$ denote significance at $0.01,0.05$,and 0.10 levels respectively. 
Table 4. Fixed Effects Estimation: Impact of Liberalization by Region

\begin{tabular}{|c|c|c|c|c|c|c|}
\hline Variable & (1) & (2) & (3) & (4) & (5) & (6) \\
\hline Intercept & $\begin{array}{c}22.474^{*} \\
(.000)\end{array}$ & $\begin{array}{c}22.414^{*} \\
(.000)\end{array}$ & $\begin{array}{c}18.702^{*} \\
(.002)\end{array}$ & $\begin{array}{c}17.983^{*} \\
(.003)\end{array}$ & $\begin{array}{c}19.893^{* * * 3} \\
(.001)\end{array}$ & $\begin{array}{c}22.064^{*} \\
(.000)\end{array}$ \\
\hline $100 *$ (Imports+Exports)/GDP & $\begin{array}{c}0.019^{* * *} \\
(.000)\end{array}$ & $\begin{array}{c}0.019^{* * * *} \\
(.000)\end{array}$ & $\begin{array}{c}0.021^{* * *} \\
(.000)\end{array}$ & $\begin{array}{c}0.022^{* * *} \\
(.000)\end{array}$ & $\begin{array}{c}0.019^{* * *} \\
(.000)\end{array}$ & $\begin{array}{c}0.021^{* * *} \\
(.000)\end{array}$ \\
\hline Log (Phones per 1000 population) & $\begin{array}{c}0.313^{* *} \\
(.015)\end{array}$ & $\begin{array}{c}0.338^{* * *} \\
(.009)\end{array}$ & $\begin{array}{c}0.289^{* *} \\
(.023)\end{array}$ & $\begin{array}{c}0.316^{* *} \\
(.012)\end{array}$ & $\begin{array}{c}0.299^{* *} \\
(.020)\end{array}$ & $\begin{array}{c}0.314^{* *} \\
(.015)\end{array}$ \\
\hline $100 * \mathrm{M} 2 / \mathrm{GDP}$ & $\begin{array}{c}0.013^{* *} \\
(.027)\end{array}$ & $\begin{array}{c}0.013^{* *} \\
(.025)\end{array}$ & $\begin{array}{c}0.015^{* *} \\
(.011)\end{array}$ & $\begin{array}{c}0.017^{* * *} \\
(.004)\end{array}$ & $\begin{array}{l}0.010^{*} \\
(.082)\end{array}$ & $\begin{array}{c}0.014^{* *} \\
(.017)\end{array}$ \\
\hline LGDPC $=$ Log $($ GDP per Capita $)$ & $\begin{array}{c}-6.414^{* * *} \\
(.000)\end{array}$ & $\begin{array}{c}-6.353^{* * *} \\
(.000)\end{array}$ & $\begin{array}{c}-5.518^{* * * *} \\
(.001)\end{array}$ & $\begin{array}{c}-5.334^{* * *} \\
(.001)\end{array}$ & $\begin{array}{c}-5.741^{* * * *} \\
(.000)\end{array}$ & $\begin{array}{c}-6.387^{* * *} \\
(.000)\end{array}$ \\
\hline LGDPC *LGDPC & $\begin{array}{c}0.401^{* * *} \\
(.000)\end{array}$ & $\begin{array}{c}0.394^{* * *} \\
(.000)\end{array}$ & $\begin{array}{c}0.349^{* * *} \\
(.001)\end{array}$ & $\begin{array}{c}0.332^{* * *} \\
(.001)\end{array}$ & $\begin{array}{c}0.360^{* * *} \\
(.001)\end{array}$ & $\begin{array}{c}0.405^{* * *} \\
(.000)\end{array}$ \\
\hline GDP Growth & $\begin{array}{c}0.024^{* *} \\
(.016)\end{array}$ & $\begin{array}{c}0.025^{* *} \\
(.012)\end{array}$ & $\begin{array}{l}0.021^{* * *} \\
(.029)\end{array}$ & $\begin{array}{c}0.020^{* *} \\
(.035)\end{array}$ & $\begin{array}{l}0.021^{* * *} \\
(.030)\end{array}$ & $\begin{array}{c}0.023^{* *} \\
(.030)\end{array}$ \\
\hline Number of Strikes & $\begin{array}{c}-0.142^{* *} \\
(.048)\end{array}$ & $\begin{array}{c}-0.141^{* *} \\
(.048)\end{array}$ & $\begin{array}{c}-0.140^{* *} \\
(.048)\end{array}$ & $\begin{array}{r}-0.131^{*} \\
(.062)\end{array}$ & $\begin{array}{r}-0.136^{*} \\
(.058)\end{array}$ & $\begin{array}{r}-0.143^{* *} \\
(.047)\end{array}$ \\
\hline Enforcement of Contracts & $\begin{array}{c}0.148^{* * *} \\
(.001)\end{array}$ & $\begin{array}{c}0.137^{* * *} \\
(.003)\end{array}$ & $\begin{array}{c}0.156^{* * *} \\
(.001)\end{array}$ & $\begin{array}{c}0.151^{* * *} \\
(.001)\end{array}$ & $\begin{array}{c}0.166^{* * *} \\
(.000)\end{array}$ & $\begin{array}{c}0.139^{* * * *} \\
(.002)\end{array}$ \\
\hline $\begin{array}{l}\text { Share of oil in Total Exports } \\
\text { (Percent) }\end{array}$ & $\begin{array}{c}-0.023^{* * *} \\
(.000)\end{array}$ & $\begin{array}{c}-0.022^{* * *} \\
(.000)\end{array}$ & $\begin{array}{c}-0.026^{* * *} \\
(.000)\end{array}$ & $\begin{array}{c}-0.025^{* * *} \\
(.000)\end{array}$ & $\begin{array}{c}-0.022^{* * *} \\
(.000)\end{array}$ & $\begin{array}{c}-0.024^{* * *} \\
(.000)\end{array}$ \\
\hline $\begin{array}{l}\mathrm{KA}=\operatorname{lag} \text { (Dummy equals } 1 \text { if capital } \\
\text { accounts is open). }\end{array}$ & $\begin{array}{l}0.543^{* * *} \\
(.006)\end{array}$ & $\begin{array}{l}0.556^{* * *} \\
(.007)\end{array}$ & $\begin{array}{l}1.633^{* * *} \\
(.000)\end{array}$ & $\begin{aligned} &- 0.003 \\
&(.988)\end{aligned}$ & $\begin{array}{l}0.603^{* * *} \\
(.004)\end{array}$ & $\begin{array}{l}0.178 \\
(.495)\end{array}$ \\
\hline $\begin{array}{l}\mathrm{ER}=\text { lag (Equals } 1 \text { if exchange rate } \\
\text { structure is unitary) }\end{array}$ & $\begin{array}{l}0.537^{* * * *} \\
(.000)\end{array}$ & $\begin{array}{l}0.585^{* * *} \\
(.000)\end{array}$ & $\begin{array}{l}0.577^{* * *} \\
(.007)\end{array}$ & $\begin{array}{l}0.482^{* * *} \\
(.001)\end{array}$ & $\begin{array}{c}0.464^{* * * *} \\
(.003)\end{array}$ & $\begin{array}{l}0.313^{*} \\
(.063)\end{array}$ \\
\hline $\begin{array}{l}\text { EX=lag (Equals } 1 \text { if there are no } \\
\text { restrictions on export proceeds) }\end{array}$ & $\begin{array}{l}0.619^{* * * *} \\
(.001)\end{array}$ & $\begin{array}{c}0.694^{* * *} \\
(.000)\end{array}$ & $\begin{array}{c}-0.393 \\
(.121)\end{array}$ & $\begin{array}{l}0.972^{* * *} \\
(.000)\end{array}$ & $\begin{array}{l}0.780^{* * *} \\
(.000)\end{array}$ & $\begin{array}{l}0.918^{* * *} \\
(.000)\end{array}$ \\
\hline $\mathrm{KA}^{*}$ Dummy for Sub-Saharan Africa & & $\begin{array}{l}-0.099 \\
(.908)\end{array}$ & & & & \\
\hline ER* Dummy for Sub-Saharan Africa & & $\begin{array}{l}-0.216 \\
(.553)\end{array}$ & & & & \\
\hline
\end{tabular}




\begin{tabular}{|c|c|c|c|c|c|c|}
\hline EX* Dummy for Sub-Saharan Africa & & $\begin{array}{c}-0.806 \\
(.247)\end{array}$ & & & & \\
\hline KA* Dummy for Latin America & & & $\begin{array}{c}-1.778^{* * *} \\
(.000)\end{array}$ & & & \\
\hline ER* Dummy for Latin America & & & $\begin{array}{c}-0.215 \\
(.457)\end{array}$ & & & \\
\hline EX* Dummy for Latin America & & & $\begin{array}{c}2.016^{* * *} \\
(.000)\end{array}$ & & & \\
\hline KA* Dummy for East Asia \& Pacific & & & & $\begin{array}{c}3.768^{* * *} \\
(.000)\end{array}$ & & \\
\hline ER* Dummy for East Asia \& Pacific & & & & $\begin{array}{l}0.495 \\
(.542)\end{array}$ & & \\
\hline EX* Dummy for East Asia \& Pacific & & & & $\begin{array}{c}-1.375^{* * *} \\
(.001)\end{array}$ & & \\
\hline KA* Dummy for Middle East \& & & & & & -0.283 & \\
\hline North Africa & & & & & $(.681)$ & \\
\hline ER* Dummy for Middle East \& & & & & & 0.152 & \\
\hline North Africa & & & & & $(.773)$ & \\
\hline EX* Dummy for Middle East \& & & & & & $-1.248^{* *}$ & \\
\hline North Africa & & & & & $(.039)$ & \\
\hline KA* Dummy for Emerging Markets & & & & & & $\begin{array}{c}1.053^{* * *} \\
(.000)\end{array}$ \\
\hline ER* Dummy for Emerging Markets & & & & & & $\begin{array}{c}1.157^{* * *} \\
(.000)\end{array}$ \\
\hline EX* Dummy for Emerging Markets & & & & & & $\begin{array}{l}0.194 \\
(.490)\end{array}$ \\
\hline Number of Countries & 75 & 75 & 75 & 75 & 75 & 75 \\
\hline Number of Observations & 1398 & 1398 & 1398 & 1398 & 1398 & 1398 \\
\hline
\end{tabular}

Notes: P-values are in parenthesis and $* * *, * *$, and $*$ denote significance at $0.01,0.05$, and 0.10 levels respectively. 


\section{Table 5. FDI Gains from Liberalization, by Region}

\begin{tabular}{lccc}
\hline Region & Capital Account (KA) & $\begin{array}{c}\text { Structure of Exchange Rate } \\
\text { (ER) }\end{array}$ & $\begin{array}{c}\text { Repatriation of Export } \\
\text { Proceeds (EX) }\end{array}$ \\
\hline Sub-Saharan Africa & 0.457 & 0.369 & -0.112 \\
& $(.582)$ & $(.257)$ & $(.867)$ \\
East Asia \& Pacific & $3.764^{* * *}$ & 0.977 & -0.403 \\
Latin America \& Caribbean & $(.000)$ & $(.224)$ & $(.265)$ \\
& -0.144 & $0.362^{*}$ & $1.623^{* * *}$ \\
Middle East \& North Africa & $(.552)$ & $(.067)$ & $(.000)$ \\
& 0.320 & 0.616 & -0.468 \\
Emerging Market & $(.627)$ & $(.224)$ & $(.414)$ \\
& $1.053^{* * *}$ & $1.157^{* * *}$ & 0.194 \\
Developing Countries & $(.000)$ & $(.000)$ & $(.490)$ \\
& $0.543^{* * *}$ & $0.537^{* * *}$ & $0.619^{* * *}$ \\
& $(.006)$ & $(.000)$ & $(.001)$ \\
\hline
\end{tabular}

Notes: P-values are in parenthesis and $* * *, * *$, and $*$ denote significance at $0.01,0.05$, and 0.10 levels respectively. Emerging Market Countries: Argentina, Brazil, Chile, Colombia, Ecuador, Indonesia, Korea Rep, Malaysia, Mexico, Peru, Philippines, Singapore, Thailand and Venezuela. 
Table 6. Countries Grouped by Region.

\begin{tabular}{|c|c|c|c|c|}
\hline Sub-Saharan Africa & East Asia \& Pacific & $\begin{array}{c}\text { Latin America \& } \\
\text { Caribbean }\end{array}$ & $\begin{array}{c}\text { Middle East \& North } \\
\text { Africa }\end{array}$ & Other \\
\hline $\begin{array}{l}\text { Burkina Faso } \\
\text { Cameroon } \\
\text { Congo, Dem. } \\
\text { Congo, Rep } \\
\text { Cote d'Ivoire } \\
\text { Ethiopia } \\
\text { Gabon } \\
\text { Gambia } \\
\text { Ghana } \\
\text { Guinea } \\
\text { Kenya } \\
\text { Madagascar } \\
\text { Malawi } \\
\text { Mali } \\
\text { Nigeria } \\
\text { Senegal } \\
\text { Sierra Leone } \\
\text { South Africa } \\
\text { Sudan } \\
\text { Tanzania } \\
\text { Togo } \\
\text { Uganda } \\
\text { Zambia } \\
\text { Zimbabwe }\end{array}$ & $\begin{array}{l}\text { China } \\
\text { Indonesia } \\
\text { Korea, Rep } \\
\text { Malaysia } \\
\text { Mongolia } \\
\text { Papua New Guinea } \\
\text { Philippines } \\
\text { Singapore } \\
\text { Thailand }\end{array}$ & $\begin{array}{l}\text { Argentina } \\
\text { Bolivia } \\
\text { Brazil } \\
\text { Chile } \\
\text { Colombia } \\
\text { Costa Rica } \\
\text { Dominican Republic } \\
\text { Ecuador } \\
\text { El Salvador } \\
\text { Guatemala } \\
\text { Guyana } \\
\text { Haiti } \\
\text { Honduras } \\
\text { Jamaica } \\
\text { Mexico } \\
\text { Nicaragua } \\
\text { Panama } \\
\text { Paraguay } \\
\text { Peru } \\
\text { Trinidad \& Tobago } \\
\text { Uruguay } \\
\text { Venezuela }\end{array}$ & $\begin{array}{l}\text { Egypt } \\
\text { Iran } \\
\text { Israel } \\
\text { Jordan } \\
\text { Kuwait } \\
\text { Morocco } \\
\text { Oman } \\
\text { Syria } \\
\text { Tunisia } \\
\text { Yemen }\end{array}$ & $\begin{array}{l}\text { Bangladesh } \\
\text { Bulgaria } \\
\text { India } \\
\text { Pakistan } \\
\text { Poland } \\
\text { Romania } \\
\text { Sri Lanka } \\
\text { Turkey }\end{array}$ \\
\hline
\end{tabular}

